\title{
Snap Bean-Variety Trials at the Lajas Substation
}

\author{
Oscar D. Raminez and José A. Quiñones ${ }^{1}$
}

INTRODUCTION

Snap beans are among the most important vegetables grown in home gardens and in market-garden areas. A knowledge of yielding ability, days to maturity, insect and disease resistance, and adaptability to the area is needed in order to make variety recommendations. Variety trials of snap beans were conducted at the Lajas Substation to obtain some of this information.

\section{POLE BEANS}

\section{MATERIALS AND METHODS}

On September 16, 1959, five pole-bean varieties were tested at the Lajas Substation in a 5-x-5-foot Latin-square design. Each plot consisted of two rows 4 feet apart and 20 feet long. In each row 10 hills were planted 2 feet apart with two plants per hill. A 9-10-5 fertilizer at the rate of 800 pounds per acre $(1)^{2}$ was applied to the planting.

The five varieties (2) tested were Florigreen, Blue Lake 92, Blue Lake 228, Blue Lake 231, and Kentucky 191. All varieties are white-seeded and commercially grown in the United States.

Beans were harvested at the best edible and marketable stage. Seventeen pickings at intervals of a few days were made to complete the harvesting of the crop.

\section{EXPERIMENTAL RESULTS}

The results obtained are presented in tables 1 and 2.

The standard error and least differences required for significance between means in table 2 are shown in the following tabulation:

$\begin{array}{ccc}\text { llem } & 5 \text { percent } & \text { I percent } \\ \text { Difference between highest and lowest } & \mathbf{6 . 6 7} & \mathbf{8 . 6 4} \\ \text { Difference between highest and 2nd lowest } & \mathbf{6 . 2 1} & \mathbf{8 . 1 4} \\ \text { Difference between highest and 3d lowest } & 5.5 \overline{7} & \mathbf{7 . 4 5} \\ \text { Difference between highest and 4th lowest } & 4.5 \overline{5} & \mathbf{6 . 3 9}\end{array}$

The yield of variety Florigreen (3) was significantly higher at the 1-percent level than that of Kentucky 191. There were no significant differences

'Assistant Plant Breeder and Research Assistant in Plant Breeding, respectively, Agricultural Experiment Station, University of Puerto Rico, Río Piedras and Lajas, P.R.

2 Italic numbers in parentheses refer to Literature Cited, p. 31. 
between the yields of varieties Florigreen, Blue Lake 231, Blue Lake 92, and Blue Lake 228.

Besides being a high yielder, variety Florigreen proved to be highly resistant to bean-mosaic and bean-rust diseases.

TABLE 1.- Harvesting dates and maturity al harvest of 5 pole-bean varieties planled at the Lajas Substation, September 16, 1959

\begin{tabular}{|c|c|c|c|}
\hline Variety & Blooming date & Harvest dates & $\begin{array}{l}\text { Days of } \\
\text { maturity at } \\
\text { first harvest }\end{array}$ \\
\hline Florigreen & Oct. 18,1959 & $\begin{array}{l}\text { Nov. } 3,6,9,12,16,18,20,23,25,27,30 \\
\text { Dec. } 2,4,7,9,11,15\end{array}$ & 49 \\
\hline Blue Lake 231 & Oct. 19,1959 & $\begin{array}{l}\text { Nov. } 3,6,9,12,16,18,20,23,25,27,30 \\
\text { Dec. } 2,4,7,9,11,15\end{array}$ & 49 \\
\hline Blue Lake 92 & Oct. 19,1959 & $\begin{array}{l}\text { Nov. } 3,6,9,12,16,18,20,23,25,27,30 \\
\text { Dec. } 2,4,7,9,11,15\end{array}$ & 49 \\
\hline Blue Lake 228 & Oct. 19,1959 & $\begin{array}{l}\text { Nov. } 6,9,12,16,18,20,23,25,27,30 \\
\text { Dec. } 2,4,7,9,11,15\end{array}$ & 52 \\
\hline Kentucky 191 & Oct. 19,1959 & $\begin{array}{l}\text { Nov. } 3,6,9,12,16,18,20,23,25,27,30 \\
\text { Dec. } 2,4,7,9,11,15\end{array}$ & 49 \\
\hline
\end{tabular}

TABLE 2.-Tolal and mean yields of 5-pole bean varieties planted at Lajas Substation, September 16, 1959

\begin{tabular}{l|c|c|c}
\hline \multicolumn{1}{c|}{ Variety } & Total yield & Mean yield per plot & $\begin{array}{c}\text { Calculated production } \\
\text { per acre }\end{array}$ \\
\cline { 2 - 3 } & $L b$. & $L b$. & $T . / A$. \\
Florigreen & 100.65 & 20.13 & 2.74 \\
Blue Lake 231 & 81.36 & 16.27 & 2.21 \\
Blue Lake 92 & 73.22 & 14.64 & 1.98 \\
Blue Lake 228 & 70.91 & 14.18 & 1.92 \\
Kentucky 191 & 57.29 & 11.46 & 1.55 \\
\hline
\end{tabular}

Kentucky 191 was the lowest yielder of the five varieties and proved to be highly susceptible to bean mosaic, making it undesirable for commercial production.

\section{BUSH BEANS}

\section{MATERIALS AND METHODS}

In 1959 sixteen commercial varieties and six lines of bush snap beans were tried out at the Lajas Substation.

The 16 commercial varieties were planted on January 30,1959 , using a 
balanced-lattice design with five replications. Each plot consisted of two rows 3 feet apart (4) and 6 feet long. In each row 10 hills were planted 6 inches apart with 1 plant per hill. A 9-10-5 fetilizer at the rate of 1,000 pounds per acre (5) was applied to the planting.

The varieties tried were Giant Stringless (2), Improved Tendergreen (6), Plentiful (2), Seminole (7), Stringless Black Valentine (6), Stringless Greenpod (6), Tenderlong (2), Tender Pod (6), Topcrop (2), Gladess (2), Contender (2), Wade (2), Bountiful (4), Topmost (2), Criolla, and Bonita.

The six lines of snap beans were planted on December 28, 1959, using a 6-x-6-foot Latin square design. Each plot consisted of two rows 3 feet apart and 20 feet long. Each row consisted of 40 plants 6 inches apart, making a total of 80 plants per plot. A $9-10-5$ fertilizer at the rate of 800 pounds per acre (1) was applied to the planting.

The lines (8) tested were B-3365, B-3095-3, B-3076, B-3489, B-3125-x$5-2$, and B-2567-1. These lines were received from the Southeastern Vegetable Breeding Laboratory at Charleston, S. C.

In both trials the beans were harvested at the best edible and marketable stage. Four pickings at intervals of a few days were made in order to complete the harvesting of the crop.

\section{EXPERIMENTAL RESULTS}

The results obtained from experiment No. 1 using 16 bush varieties are presented in tables 3 and 4.

All varieties, except Bonita were harvested on March 18, 21, 25, and 30 , and had 48 days of maturity at that time; Bonita was harvested March 25 and 30 with 55 days of maturity.

The yield of variety Toperop was significantly higher at the 1-percent level than the yields of varieties Contender, Seminole, Bountiful, Giant Stringless, Stringless Greenpod, Improved Tendergreen, Plentiful, Stringless Black Valentine, Tenderlong, Gladess, Criolla, and Bonita. There were no significant differences between the yields of Topcrop, Wade, Tender Pod, and Topmost. These four varieties, besides being the highest yielders, were also found to be well adapted to the area.

The results obtained from experiment No. 2 using six bush lines are presented in table 5 .

The standard error and least differences required for significance between means in table 6 are shown in the following tabulation:

$\begin{array}{lcc}\text { Ilem } & 5 \text { percent } & \text { ' percent } \\ \text { Difference between highest and lowest } & 4.49 & 5.56 \\ \text { Difference between highest and 2nd lowest } & 4.28 & 5.35 \\ \text { Difference between highest and 3d lowest } & 3.99 & 5.07 \\ \text { Difference between highest and 4th lowest } & 3.61 & 4.67 \\ \text { Difference between highest and 5th lowest } & 2.97 & 4.06\end{array}$


TABLE 3.-Tolal and mean yields of 16 bush snap bean varieties planted at the Lajas Substation, January 30,1959

\begin{tabular}{l|c|c|c}
\hline \multicolumn{1}{c|}{ Variety } & Total yield & $\begin{array}{c}\text { Mean yicld per } \\
\text { plot }\end{array}$ & $\begin{array}{c}\text { Calculated produc- } \\
\text { tion per acre }\end{array}$ \\
\cline { 2 - 3 } Topcrop & Lb. & \multicolumn{1}{c}{. } & T./A. \\
Wade & 26.66 & 5.33 & 3.86 \\
Tender Pod & 23.05 & 4.61 & 3.34 \\
Topmost & 22.98 & 4.59 & 3.33 \\
Contender & 21.83 & 4.37 & 3.17 \\
Seminole & 19.35 & 3.87 & 2.80 \\
Bountiful & 18.87 & 3.77 & 2.73 \\
Giant Stringless & 18.45 & 3.69 & 2.67 \\
Stringless Greenpod & 18.36 & 3.67 & 2.66 \\
Improved Tendergreen & 18.27 & 3.65 & 2.65 \\
Plentiful & 18.18 & 3.64 & 2.64 \\
Stringless Black Valentine & 16.62 & 3.32 & 2.41 \\
Tenderlong & 15.29 & 3.06 & 2.22 \\
Gladess & 14.85 & 3.97 & 2.15 \\
Criolla & 14.26 & 2.85 & 2.06 \\
Bonita & 13.82 & 2.76 & 2.00 \\
& 13.48 & 2.70 & 1.96 \\
\hline
\end{tabular}

TABLE 4.-A summary of treatments used and results obtained in the bush snap beanvariety trial planted at the Lajas Substation, January 80,1959

\begin{tabular}{|c|c|c|c|}
\hline Variety and No. & $\begin{array}{l}\text { Treat- } \\
\text { ment } \\
\text { mean }\end{array}$ & $\begin{array}{l}\text { Better at 1-percent } \\
\text { than treatment, } \\
\text { Nos. }\end{array}$ & $\begin{array}{l}\text { Better at 5-percent } \\
\text { than treatment, } \\
\text { Nos. }\end{array}$ \\
\hline Toperop, 9 & 5.33 & $\begin{array}{c}11,4,13,1,6,2,3,5 \\
7,10,15,16\end{array}$ & $\begin{array}{c}11,4,13,1,6,2,3,5 \\
7,10,15,16\end{array}$ \\
\hline Wade, 12 & 4.61 & $5,7,10,15,16$ & $3,5,7,10,15,16$ \\
\hline Tender Pod, 8 & 4.59 & $5,7,10,15,16$ & $3,5,7,10,15,16$ \\
\hline Topmost, 14 & 4.37 & $5,7,10,15,16$ & $5,7,10,15,16$ \\
\hline Contender, 11 & 3.87 & $\ldots \ldots \ldots \ldots \ldots \ldots$ & $\ldots \ldots \ldots \ldots \ldots$ \\
\hline Seminole, 4 & 3.77 & $\ldots \ldots \ldots \ldots \ldots$ & $\cdots \ldots \ldots \ldots \ldots \ldots$ \\
\hline Bountiful, 13 & 3.69 & $\ldots \ldots \ldots \ldots$ & $\cdots \ldots \ldots$ \\
\hline Giant Stringless, 1 & 3.67 & $\ldots \ldots \ldots \ldots$ & $\ldots \ldots \ldots \ldots \ldots$ \\
\hline Stringless Greenpod, 6 & 3.65 & $\ldots \ldots \ldots \ldots$ & $\ldots \ldots \ldots \ldots$ \\
\hline Improved Tendergreen, 2 & 3.64 & $\ldots \ldots \ldots \ldots \ldots$ & $\ldots \ldots \ldots \ldots$ \\
\hline Plentiful, 3 & 3.32 & $\ldots \ldots \ldots \ldots \ldots \ldots$ & $\ldots \ldots \ldots \ldots \ldots$ \\
\hline Stringless Black Valentine, 5 & 3.015 & $\ldots \ldots \ldots \ldots \ldots$ & $\ldots \ldots \ldots \ldots \ldots \ldots$ \\
\hline Tenderlong, 7 & 2.97 & $\ldots \ldots \ldots \ldots \ldots$ & $\ldots \ldots \ldots \ldots \ldots$ \\
\hline Gladess, 10 & 2.85 & $\ldots \ldots \ldots \ldots \ldots$ & $\ldots \ldots \ldots \ldots$ \\
\hline Criolla, 15 & 2.76 & $\ldots \ldots \ldots \ldots \ldots$ & $\ldots \ldots$ \\
\hline Bonita, 16 & 2.70 & $\ldots \ldots \ldots$ & $\ldots \ldots \ldots \ldots$ \\
\hline
\end{tabular}


The blooming date for 4 of the bush lines mentioned under "Materials and Methods" above was January 27, 1960, but for B-3365 and B-3125$\mathrm{x}-5-2$ it was January 26,1960 . The harvest dates for all lines were February $10,15,19$, and 23 , and their maturity at harvest was 45 days.

No significant differences were found between the yields of the six lines of snap beans. All six lines look very promising for commercial production, taking in consideration their yielding ability, disease resistance, pod appearance and quality.

\section{SUMMARY}

Snap bean-variety trials were conducted at the Lajas Substation. Three different experiments were planted, one of pole beans and two others of bush beans.

TABLE 5.-Total and mean yields of 6 lines of snap beans planted at the Lajas Substation, December 28, 1959

\begin{tabular}{c|c|c|c}
\hline Lines & Total yicld & Mean yield per plot & $\begin{array}{c}\text { Calculated production } \\
\text { per acre }\end{array}$ \\
\cline { 2 - 3 } & Lb. & $L b$. & $T . / A$. \\
B-3125-x-5-2 & 95.21 & 15.87 & 2.88 \\
B-2567-1 & 92.22 & 15.37 & 2.78 \\
B-3095-3 & 90.89 & 15.15 & 2.74 \\
B-3365 & 90.01 & 15.00 & 2.72 \\
B-3489 & 77.64 & 12.92 & 2.34 \\
B-3076 & 69.55 & 11.59 & 2.10 \\
\hline
\end{tabular}

The five varieties of pole beans tested were Florigreen, Kentucky 191, Blue Lake 92, Blue Lake 228, and Blue Lake 231.

Of the five pole varieties tested, variety Florigreen was the highest yielder. It also showed to be highly resistant to bean-mosaic and bean-rust diseases.

Sixteen bush snap beans were also tested. They were Topcrop, Wade, Tender Pod, Topmost, Contender, Seminole, Bountiful, Giant Stringless, Stringless Greenpod, Improved Tendergreen, Plentiful, Tenderlong, Stringless Black Valentine, Gladess, Criolla, and Bonita. According to their yield and adaptability to the area, only four varieties look promising. They are Topcrop, Wade, Tender Pod, and Topmost.

Also six lines of bush snap beans received from the Southeastern Vegetable Breeding Laboratory were tested. No significant differences were found between their yields. All six lines B-3365, B-3095-3, B-3076, B-3489, B-3125-x-5-2, and B-2567-1 look very promising, taking in consideration their yielding ability, disease resistance, pod appearance, and quality. 


\section{RESUMEN}

En la Subestación de Lajas se llevaron a cabo pruebas con variedades de habichuelas tiernas. Se sembraron tres experimentos, uno de habichuelas trepadoras y dos de arbustivas.

Las cinco variedades trepadoras que se probaron fueron, Florigreen, Kentucky 191, Blue Lake 92, Blue Lake 228 y Blue Lake 231. De estas cinco variedades, la Florigreen fue la de más alta producción. También demostró ser altamente resistente a las enfermedades del mosaico y la roya de la habichuela.

Las 16 variedades de habichuelas arbustivas que se probaron fueron las siguientes: Topcrop, Wade, Tender Pod, Topmost, Contender, Seminole, Bountiful, Giant Stringless, Stringless Greenpod, Improved Tendergreen, Plentiful, Tenderlong, Stringless Black Valentine, Gladess, Criolla y Bonita. De estas variedades y de acuerdo con su producción y adaptabilidad a la zona, las siguientes resultaron superiores: Topcrop, Wade, Tender Pod y Topmost.

Se probaron también seis líneas de habichuelas arbustivas enviadas por el Laboratorio de Desarrollo de Hortalizas del Sureste de los Estados Unidos. No se encontró diferencia significativa alguna entre las producciones de estas líneas.

Las variedades B-3365, B-3095-3, B-3076, B-3489, B-3125-x-5-2 y B-2567-1 demostraron ser muy prometedoras por su capacidad productiva, resistencia a las enfermedades y por la apariencia y calidad de la vaina.

\section{LITERATURE CITED}

1. Compendio de Recomendaciones para la Producción de Cosechas, Pub. Misc. 1. Est. Exp. Agr. Univ. P.R., (rev.) 1954.

2. Asgrow Export Corp., A Descriptive Catalog of Vegetables, No. 19.

3. Walter, J. M., and Lorz, A. P., Florigreen, A Disease-Resistant Pole Bean, Circ. S-92, Fla. Agr. Exp. Sta., 1956.

4. Zaumeyer, W. J., Snap beans for Marketing, Canning, and Freezing, Farmer's Bul. 1915, U.S.D.A. (rev.) Sept. 1954.

5. González-Rios, P., y Riollano, A., El Mejoramiento de la Habichuela Blanca del País (Phaseolus vulgaris) por Medio de la Selección, Bol. 94, Est. Exp. Agr., Río Piedras, P.R.

6. W. Atlee Burpee Co., Burpee Seeds, 1959.

7. Wolf, E. A. and Hills, W. A., Seminole-A New I)isease-Resistant, Green, RoundPodded Bush Bean, Circ. S-73, Fla. Agr. Exp. Sta., 1954.

8. Nineteenth and Twentieth Annual Report of Vegetable Breeding in the Southeastern United States, Hawaii, and Puerto Rico, Southeastern Vegetable Breeding Lahoratory, Agricultural Research Service, USDA, Charleston, S.C., 1958-59. 